\title{
Effects of replacing soybean meal with canola meal or treated canola meal on ruminal digestion, omasal nutrient flow, and performance in lactating dairy cows
}

\author{
E. M. Paula, ${ }^{*}$ G. A. Broderick, $†$ M. A. C. Danes, $\ddagger$ N. E. Lobos,§ G. I. Zanton,\# and A. P. Faciolall ${ }^{1}$ \\ *Department of Agriculture, Nutrition, and Veterinary Sciences, University of Nevada, Reno 89557 \\ †Broderick Nutrition \& Research LLC, Madison, WI 53705 \\ ¥Departamento de Zootecnia, Universidade Federal de Lavras, Lavras, MG, 37200-000, Brazil \\ §Kemin Industries, Des Moines, IA 50306 \\ \#USDA Agricultural Research Service, US Dairy Forage Research Center, Madison, WI 53706 \\ IDepartment of Animal Sciences, University of Florida, Gainesville 32611
}

\begin{abstract}
Extrusion treated canola meal (TCM) was produced in an attempt to increase the rumen-undegraded protein fraction of canola meal (CM). The objective of this study was to evaluate the effects of replacing soybean meal (SBM) with CM or TCM on ruminal digestion, omasal nutrient flow, and performance in lactating dairy cows. To assess performance, 30 multiparous Holstein cows averaging (mean \pm SD) $119 \pm 23 \mathrm{~d}$ in milk and $44 \pm 7 \mathrm{~kg}$ of milk/d and 15 primiparous cows averaging $121 \pm 19 \mathrm{~d}$ in milk and $34 \pm 6 \mathrm{~kg}$ of milk/d were blocked in a randomized complete block design with a 2-wk covariate period and 12-wk experimental period (experiment 1). Dietary ingredients differed only in protein supplements, which were SBM, CM, or TCM. All diets were formulated to contain (dry matter basis) $30 \%$ alfalfa silage, $30 \%$ corn silage, $4 \%$ soy hulls, $2.4 \%$ mineral-vitamin premix, and $16 \% \mathrm{CP}$. The SBM diet contained $25 \%$ high-moisture shelled corn and $8.6 \% \mathrm{SBM}$; the canola diets contained $22 \%$ highmoisture shelled corn and either $11.2 \% \mathrm{CM}$ or $11.4 \%$ TCM. To assess ruminal digestion and omasal nutrient flow, 6 rumen-cannulated cows were blocked into 2 squares of 3 cows and randomly assigned within blocks to the same 3 dietary treatments as in experiment 1 in a replicated $3 \times 3$ Latin square design (experiment 2 ). Data were analyzed using the MIXED procedure of SAS (SAS Institute, Cary, NC). Orthogonal contrasts were used to compare effects of different protein supplements: SBM versus CM + TCM and CM versus TCM. In experiment 1, compared with SBM, apparent totaltract digestibilities of dry matter and nutrients were greater in cows fed both CM diets, and there was a
\end{abstract}

Received June 23, 2017.

Accepted September 19, 2017.

${ }^{1}$ Corresponding author: afaciola@ufl.edu tendency for nutrient digestibilities to be higher in cows fed CM compared with TCM. Diets did not affect milk yield and milk components; however, both canola diets decreased urinary urea $\mathrm{N}$ (\% of total urinary $\mathrm{N}$ ), fecal $\mathrm{N}$ (\% of total $\mathrm{N}$ intake), and milk urea $\mathrm{N}$ concentration. In experiment 2, compared with SBM, both canola diets increased $\mathrm{N}$ intake and tended to increase rumendegraded protein supply $(\mathrm{kg} / \mathrm{d})$ and $\mathrm{N}$ truly digested in the rumen $(\mathrm{kg} / \mathrm{d})$. Diets did not affect ruminal digestibility, efficiency of microbial protein synthesis, and rumen-undegraded protein flow among diets. Results from this experiment indicate that replacing SBM with CM or TCM in diets of lactating cows improved digestibility and may reduce environmental impact. Moreover, under the conditions of the present study, treating CM by extrusion did not improve CM utilization.

Key words: canola meal, extrusion, nitrogen metabolism, rumen-undegraded protein

\section{INTRODUCTION}

Canola meal (CM) is widely used in North America as a protein supplement for lactating dairy cows. Previous studies comparing the effects of soybean meal (SBM) or other protein supplements versus CM have shown that $\mathrm{CM}$ diets increase nitrogen $(\mathrm{N})$ utilization and performance when fed to lactating dairy cows (Huhtanen et al., 2011; Broderick et al., 2015). Improvement in $\mathrm{N}$ utilization and performance using $\mathrm{CM}$ in dairy cows diets may be attributable to an increase in microbial protein synthesis or a greater MP supply from the RUP fraction (Maxin et al., 2013a). However, it is still unclear whether responses observed when CM is fed are due to a ruminal effect, a postruminal effect, or a combination of both.

Chemical and physical treatments are strategies used to increase the RUP fraction of protein supplements with the goal of increasing AA availability for absorption in the small intestine and consequently optimizing 
the performance of dairy cows (Santos et al., 1998; Huhtanen et al., 2011). This strategy has been widely used with SBM, and many SBM-based commercial products have been developed as a consequence. However, studies evaluating the response of treated CM (TCM) on the performance of dairy cows have been inconsistent. For instance, Rinne et al. (1999) found no difference between the effect of rapeseed meal and heat-moisture-treated rapeseed cake on yields of milk. Conversely, Wright et al. (2005) found an increase in milk yield in cows fed heat-treated CM plus lignosulfonate compared with untreated CM.

In a meta-analysis, Huhtanen et al. (2011) did not find differences in DMI, digestibility, and milk yield when comparing regular CM versus heat-treated CM. Paula et al. (2017) did not find differences in RUP and microbial protein synthesis flow when comparing CM differing in RUP content in an in vitro study using a dual-flow continuous culture system. Furthermore, Ahvenjärvi et al. (1999) did not observe differences in omasal NAN and microbial NAN flow in cows fed either rapeseed meal or heat-moisture-treated rapeseed cake. Similarly, Khorasani et al. (1993) did not find differences in ruminal $\mathrm{CP}$ degradability in cows fed $\mathrm{CM}$ or CM treated with acetic acid. However, to our knowledge, no studies have measured omasal nutrient and microbial protein flow when TCM is fed as the major protein supplement in corn- or alfalfa silage-based diets to lactating dairy cows.

In the present study, CM was treated by extrusion in an attempt to increase its RUP content. We hypothesized that (1) feeding TCM would improve RUP flow to the small intestine, $\mathrm{N}$ utilization, and performance of dairy cows compared with regular solvent-extracted CM and (2) both CM diets would improve N utilization and performance of dairy cows compared with regular solvent-extracted SBM. Therefore, the objectives of the present study were (1) to evaluate the effects of SBM, $\mathrm{CM}$, and TCM on ruminal digestion and omasal nutrient flow and (2) to measure total-tract digestibility, N metabolism, and production performance of lactating dairy cows.

\section{MATERIALS AND METHODS}

Care and handling of all experimental animals, including ruminal cannulation, were conducted under protocols approved by the University of Wisconsin Institutional Animal Care and Use Committee.

\section{Experiment 1}

Experiment 1 was designed to avoid potential carryover effects from reversal experiments; moreover, it allowed cows to stay on the same diet longer, which could have the potential to better reflect the effects of the protein supplement on milk production. At the beginning of the study, 30 multiparous Holstein cows averaging (mean $\pm \mathrm{SD}$ ) $2.5 \pm 0.6$ parity, $660 \pm 55 \mathrm{~kg}$ of BW, $119 \pm 23 \mathrm{DIM}$, and $44 \pm 7 \mathrm{~kg}$ of milk/d and 15 primiparous cows averaging $592 \pm 34 \mathrm{~kg}$ of BW, 121 $\pm 19 \mathrm{DIM}$, and $34 \pm 6 \mathrm{~kg}$ of milk/d were blocked into groups of 3 by parity and DIM to obtain 10 multiparous blocks and 5 primiparous blocks in a randomized complete block design study. Cows were fed a control diet for a 2-wk covariate period and then switched to the experimental diets for a 12 -wk study. The control diet contained (DM basis) 30\% alfalfa silage, 30\% corn silage, $22.2 \%$ high-moisture shelled corn (HMSC), 4.3\% SBM, 5.8\% regular CM, $5.3 \%$ soy hulls, and $2.4 \%$ mineral-vitamin premix. The $\mathrm{CM}$ was treated by extrusion, with added molasses $(2-3 \%)$ to promote the browning reaction. The meal was preconditioned with steam containing reducing sugars and a proprietary blend of carbohydrases to a moisture level of $15 \%$, then treated using a HTST annular gap expander (Kahl GmbH, Reinbek, Germany). The expander had a cone pressure of 13 bars. The same batch of meal was used for CM and TCM during the entire experimental period. Chemical composition of the fermented feeds and protein supplements fed is shown in Table 1. All diets contained (DM basis) 30\% alfalfa silage, 30\% corn silage, $4 \%$ soy hulls, and $2.4 \%$ mineral-vitamin premix plus one of the following protein supplements: SBM (8.4\%), CM (11.2\%), or TCM (11.4\%). The HMSC was decreased from $25 \%$ in the SBM diet to $22 \%$ in both $\mathrm{CM}$ diets. Dietary CP contents were approximately $16 \%$ for all diets (Table 2).

All cows were injected biweekly with recombinant bST (500 mg of Posilac, Elanco Animal Health, Greenfield, IN). Cows were housed in tiestalls and had free access to water during the experiment.

Diets were offered once daily at $1000 \mathrm{~h}$. Orts were collected and weights were recorded at $0900 \mathrm{~h}$, and feeding rate was adjusted daily to yield orts between 5 to $10 \%$ of intake. Weekly composite samples (500 g) were taken from daily samples of corn silage, alfalfa silage, HMSC, $\mathrm{TMR}$, and orts and stored at $-20^{\circ} \mathrm{C}$ until analysis. Weekly samples of SBM, CM, TCM, and soy hulls were also taken and stored at room temperature. The DM content was determined in weekly composites of corn silage, alfalfa silage, and HMSC by drying at $60^{\circ} \mathrm{C}$ for $48 \mathrm{~h}$ and in weekly samples of SBM, CM, TCM, and soy hulls at $105^{\circ} \mathrm{C}$ according to AOAC (1990). Weekly samples of feed ingredients were also analyzed for total $\mathrm{N}$ using a combustion assay (Leco FP-2000 N Analyzer, Leco Instruments Inc., St. Joseph, MI) according to AOAC International (2005) method 990.13. Ingredient 
PAULA ET AL.

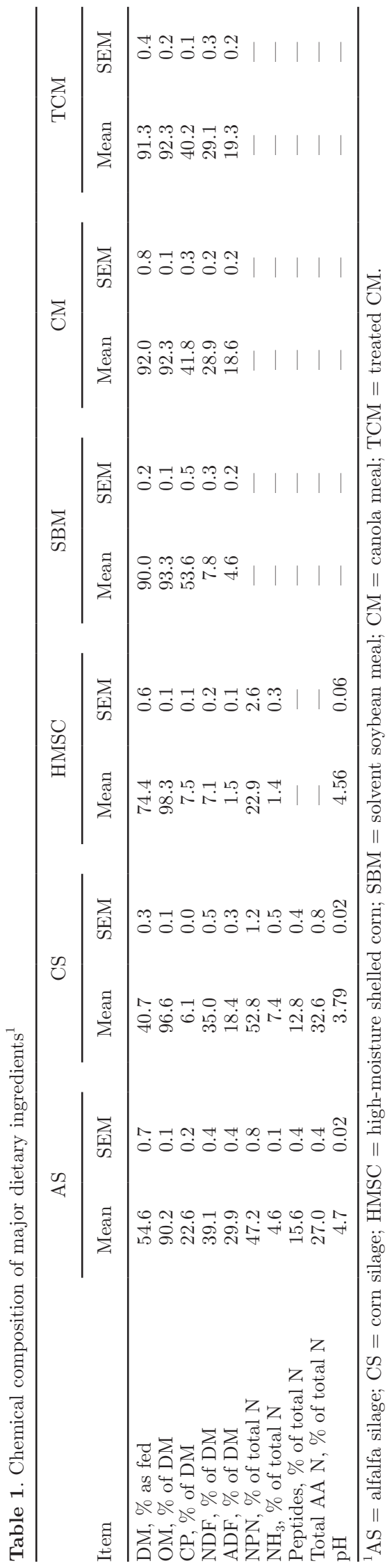

Table 2. Dietary ingredients and chemical composition (\% of DM unless otherwise stated)

\begin{tabular}{|c|c|c|c|}
\hline \multirow[b]{2}{*}{ Item } & \multicolumn{3}{|c|}{$\operatorname{Diet}^{1}$} \\
\hline & SBM & $\mathrm{CM}$ & $\mathrm{TCM}$ \\
\hline Alfalfa silage & 31.3 & 31.2 & 31.3 \\
\hline Corn silage & 28.9 & 28.8 & 28.8 \\
\hline High-moisture shelled corn & 25.1 & 22.3 & 22.4 \\
\hline Solvent soybean meal & 8.4 & - & - \\
\hline Canola meal & - & 11.2 & - \\
\hline Treated canola meal & - & - & 11.4 \\
\hline Soy hulls & 3.93 & 3.92 & 3.93 \\
\hline Vitamin and mineral premix ${ }^{2}$ & 2.45 & 2.48 & 2.48 \\
\hline \multicolumn{4}{|l|}{ Chemical composition } \\
\hline DM, \% & 55.8 & 55.9 & 55.4 \\
\hline $\mathrm{OM}$ & 92.3 & 92.1 & 92.3 \\
\hline $\mathrm{NDF}$ & 27.1 & 29.5 & 29.6 \\
\hline $\mathrm{ADF}$ & 17.2 & 18.8 & 18.9 \\
\hline $\mathrm{CP}$ & 15.7 & 15.7 & 15.6 \\
\hline $\mathrm{RDP}^{3}$ & 10.2 & 11.1 & 11.1 \\
\hline RUP $^{4}$ & 5.2 & 5.0 & 4.8 \\
\hline $\mathrm{NFC}^{5}$ & 44.5 & 42.8 & 39.6 \\
\hline $\mathrm{Fat}^{6}$ & 2.88 & 2.96 & 2.96 \\
\hline $\mathrm{NE}_{\mathrm{L}},{ }^{7} \mathrm{Mcal} / \mathrm{kg}$ of DM & 1.55 & 1.54 & 1.57 \\
\hline
\end{tabular}

${ }^{1} \mathrm{SBM}=$ dietary treatment with solvent soybean meal as protein supplement; $\mathrm{CM}=$ dietary treatment with canola meal as protein supplement; TCM $=$ dietary treatment with treated canola meal as protein supplement.

${ }^{2}$ Provided (per $\mathrm{kg}$ of DM): $56 \mathrm{mg}$ of $\mathrm{Zn}, 46 \mathrm{mg}$ of Mn, $22 \mathrm{mg}$ of Fe, 12 $\mathrm{mg}$ of $\mathrm{Cu}, 0.9 \mathrm{mg}$ of I, $0.4 \mathrm{mg}$ of $\mathrm{Co}, 0.3 \mathrm{mg}$ of Se, 6,440 IU of vitamin A, 2,000 IU of vitamin D, $16 \mathrm{IU}$ of vitamin E, and $12 \mathrm{mg}$ of monensin. ${ }^{3}$ Calculated from experiment 2 as RDP, $\%$ of $\mathrm{DM}=$ (total CP intake, $\mathrm{kg} / \mathrm{d}$ - omasal RUP flow, $\mathrm{kg} / \mathrm{d}) \times 100 / \mathrm{DMI}, \mathrm{kg} / \mathrm{d}$.

${ }^{4}$ Calculated from experiment 2 as RUP, $\%$ of DM $=$ (total omasal CP flow, $\mathrm{kg} / \mathrm{d}-$ omasal microbial CP flow, $\mathrm{kg} / \mathrm{d}) \times 100 / \mathrm{DMI}, \mathrm{kg} / \mathrm{d}$.

${ }^{5} \mathrm{NFC}=100-(\% \mathrm{NDF}+\% \mathrm{CP}+\%$ fat $+\%$ ash $)$ according to the NRC (2001) model.

${ }^{6} \mathrm{Fat}$ contents of individual dietary ingredients were used from the NRC (2001) nutrient composition tables.

${ }^{7}$ Estimated using the NRC (2001) model.

DM and $\mathrm{N}$ were used to adjust dietary composition weekly to maintain constant DM proportions from each feed ingredient and $\mathrm{CP}$ contents in each diet. The DMI was computed daily based on the $60^{\circ} \mathrm{C} \mathrm{DM}$ determinations for TMR and orts. After drying, ingredients and TMR were ground to pass a 1-mm screen (Wiley mill, Arthur H. Thomas, Philadelphia, PA). Samples were analyzed for DM (method 934.01), ash, and OM (method 938.08) according to AOAC (1990) and total $\mathrm{N}$ as previously described. Samples were sequentially analyzed for $\mathrm{NDF}$ and $\mathrm{ADF}$ after being treated with thermo-stable $\alpha$-amylase and $\mathrm{Na}_{2} \mathrm{SO}_{3}$ according to Van Soest et al. (1991) and adapted for the Ankom200 Fiber Analyzer (Ankom Technology, Macedon, NY). Indigestible $\mathrm{ADF}$ was analyzed in the $\mathrm{ADF}$ residue remaining after $12 \mathrm{~d}$ of in situ incubation according to Huhtanen et al. (1994).

Cows were milked 3 times daily at 0300, 1100, and $1700 \mathrm{~h}$, and milk yield was recorded at each milking 
time during the entire experiment. Milk samples from all 3 daily milkings were collected on the last $4 \mathrm{~d}$ of wk 4, 6, 8, 10, and 12 and were analyzed for fat, true protein, lactose, SNF, and MUN by infrared analysis (AgSource, Verona, WI) with a spectrum analyzer (FT6000; Foss North America Inc., Eden Prairie, MN) using AOAC (1990) method 972.16. Concentrations and yields of fat, true protein, lactose, SNF, and MUN were calculated as weighted means based on morning, afternoon, and evening milk yields on each test day. Yields of 3.5\% FCM were calculated according to Sklan et al. (1992), and yields of ECM were calculated as described by Krause and Combs (2003).

Efficiencies of feed conversion were calculated for each cow over wk $4,6,8,10$, and 12 by dividing the average yield of actual milk and ECM by the respective DMI. Efficiency of feed $\mathrm{N}$ utilization was calculated for each cow by dividing mean milk $\mathrm{N}$ output (milk true protein/6.38) by mean milk $\mathrm{N}$ intake, assuming no net deposit or mobilization of $\mathrm{N}$ from body tissues.

On the last day of wk 4, 8, and 12, 2 spot urine and 2 spot fecal samples were collected from each cow $6 \mathrm{~h}$ before and $6 \mathrm{~h}$ after feeding. Fecal samples were dried in a forced-draft oven $\left(60^{\circ} \mathrm{C} ; 72 \mathrm{~h}\right)$ and ground to pass a $1-\mathrm{mm}$ screen (Wiley mill). Equal DM from each fecal subsample was combined to obtain one composite sample for each cow in wk 4, 8, and 12 . Fecal samples were analyzed for total DM, ash, OM, $\mathrm{N}, \mathrm{NDF}, \mathrm{ADF}$, and indigestible $\mathrm{ADF}$ as described for feed analysis. Indigestible ADF was used as an internal marker to estimate apparent total-tract digestibility and fecal output, using the respective DMI, according to Cochran et al. (1986). Urine samples were acidified immediately after collection by diluting 1 volume of urine with 4 volumes of $0.072 \mathrm{~N} \mathrm{H}_{2} \mathrm{SO}_{4}$ and stored at $-20^{\circ} \mathrm{C}$ until analysis. Before the analysis, urine samples were thawed at room temperature and filtered through Whatman No. 1 filter paper. Filtrates were analyzed for creatinine using a picric acid method (Oser, 1965) adapted to flow-injection analysis (Lachat Quik-Chem 8000 FIA; Lachat Instruments, Milwaukee, WI) and for total N using an N analyzer (Leco FP-2000 N Analyzer; Leco Instruments Inc.). In addition, filtrates were analyzed for allantoin using the method of Vogels and Van der Drift (1970) adapted to a 96-well plate reader, for uric acid using a commercial kit (no. 683-100P, Sigma Chemical Co., St Louis, MO), and for urea with the colorimetric method (Broderick and Clayton, 1997). Daily urine volume was calculated based on individual BW and using a creatinine excretion rate of $29 \mathrm{mg} / \mathrm{kg}$ of BW (Valadares et al., 1999). Urinary urea N, total $\mathrm{N}$, total purine derivatives (PD), and allantoin plus uric acid were calculated based on their individual daily excretion multiplied by daily urine volume.

\section{Experiment 2}

Experiment 2 was run in parallel with experiment 1 with 6 ruminally cannulated cows to assess ruminal digestion and omasal nutrient flow. At the beginning of the study, 4 multiparous Holstein rumen-cannulated cows averaging (mean $\pm \mathrm{SD}$ ) $694 \pm 56 \mathrm{~kg}$ of BW, 220 $\pm 71 \mathrm{DIM}$, and $34.7 \pm 9 \mathrm{~kg}$ of milk/d and 2 primiparous Holstein rumen-cannulated cows averaging $680 \pm$ $6 \mathrm{~kg}$ of BW, $242 \pm 2 \mathrm{DIM}$, and $32.6 \pm 2 \mathrm{~kg}$ of milk/d were used. Cows were randomly assigned to treatment sequences in a replicate $3 \times 3$ Latin square design with $21 \mathrm{~d}$ of diet adaptation and $7 \mathrm{~d}$ of sampling. Dietary treatments were as described for experiment 1.

Omasal sampling was performed each period using the technique developed by Huhtanen et al. (1997) and Ahvenjärvi et al. (2000) and adapted by Reynal and Broderick (2005) to quantify digesta flow out of the rumen. External markers were used to estimate nutrient flow at the omasal canal: indigestible NDF (Huhtanen et al., 1994), $\mathrm{YbCl}_{3}$ (Siddons et al., 1985), and cobalt-EDTA (Udén et al., 1980) were used as markers for large particles, small particles, and fluid phases of digesta, respectively. The external microbial marker ${ }^{15} \mathrm{~N}$ was used to quantify microbial NAN flow from the rumen. Before marker infusion began, approximately $100 \mathrm{~g}$ of ruminal contents was taken from each cow to determine the background ${ }^{15} \mathrm{~N}$ abundance. Cobalt-EDTA, $\mathrm{YbCl}_{3}$, and ${ }^{15} \mathrm{NH}_{4} \mathrm{SO}_{4}$ containing $10 \%$ atom excess ${ }^{15} \mathrm{~N}$ (Isotec, Miamisburg, $\mathrm{OH}$ ) were dissolved in distilled water and continuously infused into the rumen at a rate of $2.6 \mathrm{~g}$ of cobalt-EDTA, $3.2 \mathrm{~g}$ of $\mathrm{YbCl}_{3}$, and $231 \mathrm{mg}$ of ${ }^{15} \mathrm{~N} / \mathrm{d}$ in $2.89 \mathrm{~L}$ of solution/d. Markers were continuously infused from d 22 to 28 using a peristaltic pump (AutoAnalyzer II, Technicon Corp., St. Louis, MO).

Beginning on d 26, omasal samples were collected at 12 time points in 2 -h intervals over a 3 -d period to represent a 24-h feeding cycle. Sampling protocols, including confirming that the sample tubes were correctly positioned in the omasal canal, sampling time and volumes, sample processing, isolation of fluid and particle-associated bacteria, digesta marker analyses, and preparation of omasal true digesta, were performed according to Reynal and Broderick (2005) and Brito et al. (2007) except that ammonia and protozoa were not isolated for determination of ${ }^{15} \mathrm{~N}$ enrichment. At each sampling time, $325 \mathrm{~mL}$ of omasal sample was collected and split into 2 subsamples (125 and $200 \mathrm{~mL}$ ). The four $125-\mathrm{mL}$ subsamples were pooled and stored on ice to yield a daily composite of $500 \mathrm{~mL}$ from each cow, which was used for bacterial isolation. The four 200-mL subsamples were pooled and stored at $-20^{\circ} \mathrm{C}$ over the $3 \mathrm{~d}$ to obtain a single 2.4-L composite from each cow 
in each period for late separation into the 3 omasal phases.

The triple marker technique of France and Siddons (1986) was used to determine the proportions to recombine the 3 phases to produce omasal true digesta. Samples of omasal true digesta were analyzed for total $\mathrm{N}, \mathrm{DM}\left(105^{\circ} \mathrm{C}\right)$, ash, OM, NDF, and ADF as described previously for feed samples in experiment 1. Samples of true digesta and isolated bacteria were treated with $\mathrm{K}_{2} \mathrm{CO}_{3}$ (Brito et al., 2007) to remove residual ammonia and were analyzed for total $\mathrm{N}$ (equivalent to NAN) and for ${ }^{15} \mathrm{~N}$ abundance using a Costech 4010 elemental analyzer (Costech Analytical Technologies Inc., Valencia, CA) interfaced to a Thermo-Finnigan Delta-Plus Advantage isotope ratio mass spectrometer (Thermo-Electron GmbH, Bremen, Germany). Flows of dietary nutrients and microbial origin and extents of ruminal digestion were calculated using the procedures described by Brito et al. (2007).

On d 27 of each period, approximately $150 \mathrm{~mL}$ of digesta was collected from 3 locations in the rumen at 0 (before feeding), 2, 4, 6, 8, 12, 18, and $22 \mathrm{~h}$ after feeding and strained through 2 layers of cheesecloth, and $\mathrm{pH}$ was measured immediately using a glass electrode. Two 10-mL samples of ruminal fluid were preserved in scintillation vials by addition of $0.2 \mathrm{~mL}$ of $50 \% \mathrm{H}_{2} \mathrm{SO}_{4}$ and stored at $-20^{\circ} \mathrm{C}$. Before analysis, samples were thawed and centrifuged at $15,300 \times g$ for $20 \mathrm{~min}$ at $4^{\circ} \mathrm{C}$. Flow-injection analyses (Lachat Quik-Chem 8000 FIA; Lachat Instruments) were applied to supernatants to determine ammonia, using a phenol-hypochlorite method (Lachat method 18-107-06-1-A; Lachat), and total AA, using a fluorometric procedure based on the reaction with $o$-phthaldialdehyde (Roth, 1971). Leucine was the standard in the $o$-phthaldialdehyde assay, and total AA are reported in Leu equivalents. Samples were also thawed and centrifuged $(30,000 \times g$ for $30 \mathrm{~min}$ at $4^{\circ} \mathrm{C}$ ) for determination of individual and total ruminal VFA using a modification of the gas-liquid chromatography method for free fatty acids described by Brotz and Schaefer (1987) with flame-ionization detection. Standards and supernatants $(0.5$ or $1 \mu \mathrm{L})$ were injected onto a ZB-FFAP capillary column $(30 \mathrm{~m} \times 0.53 \mathrm{~mm} \times$ $1.0 \mu \mathrm{m}$; no. 7HK-G009-22; Phenomenex Inc., Torrance, $\mathrm{CA}$ ) with helium carrier gas at $100 \mathrm{kPa}$ and a flow rate of $20 \mathrm{~mL} / \mathrm{min}$. Column oven temperature was $100^{\circ} \mathrm{C}$ at injection; after $2 \mathrm{~min}$, the temperature was increased to $130^{\circ} \mathrm{C}$ at a rate of $10^{\circ} \mathrm{C} / \mathrm{min}$. Injector and detector temperatures were 230 and $250^{\circ} \mathrm{C}$, respectively. This method did not resolve isovalerate and 2-methyl butyrate, which are reported as isovalerate plus 2-methylbutyrate.

\section{Statistical Analysis}

Experiment 1. Data were analyzed as a randomized complete block design with the data from the preliminary 2-wk covariate period using the MIXED procedure of SAS (2003, SAS Institute Inc., Cary, NC) with week of treatment as the repeated measure using the first order compound symmetry covariance structure. The covariance structure of compound symmetry was selected based on best-fit Akaike information criterion. The following model was used to fit the data to assess least squares means for intake and lactation performance:

$$
\begin{gathered}
\mathrm{Y}_{\mathrm{ijklm}}=\mu+\operatorname{Cov}_{\mathrm{i}}+\mathrm{B}_{\mathrm{j}}+\mathrm{W}_{\mathrm{k}}+\mathrm{D}_{\mathrm{l}}+\mathrm{DW}_{\mathrm{lk}} \\
+\mathrm{C}_{\mathrm{m}(\mathrm{j})}+\mathrm{e}_{\mathrm{ijk} \mathrm{km}},
\end{gathered}
$$

where $\mathrm{Y}_{\mathrm{ijklm}}=$ dependent variable, $\mu=$ overall mean, $\mathrm{Cov}_{\mathrm{i}}=$ effect of covariate period $\mathrm{i}, \mathrm{B}_{\mathrm{j}}=$ effect of block $\mathrm{j}$, $\mathrm{W}_{\mathrm{k}}=$ effect of week $\mathrm{k}, \mathrm{D}_{1}=$ effect of dietary treatment $\mathrm{l}, \mathrm{DW}_{\mathrm{lk}}=$ interaction between diet $\mathrm{l}$ and week $\mathrm{k}, \mathrm{C}_{\mathrm{m}(\mathrm{j})}$ = effect of cow $\mathrm{m}$ (within block $\mathrm{j}$ ), and $\mathrm{e}_{\mathrm{ijk} k \mathrm{~m}}=$ residual error. All terms were considered fixed except for $\mathrm{C}_{\mathrm{m}(\mathrm{j})}$ and $\mathrm{e}_{\mathrm{ijklm}}$, which were considered random. Degrees of freedom were calculated using the between-within option. Orthogonal contrasts were used to compare the effects of different protein supplements: SBM versus CM + TCM and CM versus TCM. For apparent total-tract digestibility and excretion, the same model was used except that the covariate period was removed from the model. Statistical differences were declared at $P \leq 0.05$, and trends were declared at $0.05<P \leq 0.10$.

Experiment 2. Statistical analyses were performed as a replicate $3 \times 3$ Latin square design using the MIXED procedure of SAS (2003, SAS Institute Inc.). One cow injured its foot during the third feeding period and was dropped from the study. The results of the first 2 feeding periods of the injured cow were included in the statistical analysis. The following model was used to fit the data to assess effects of dietary treatments:

$$
\mathrm{Y}_{\mathrm{ijkl}}=\mu+\mathrm{S}_{\mathrm{i}}+\mathrm{P}_{\mathrm{j}}+\mathrm{C}(\mathrm{S})_{\mathrm{ki}}+\mathrm{T}_{1}+\mathrm{ST}_{\mathrm{il}}+\mathrm{e}_{\mathrm{ijkl}},
$$

where $Y_{\mathrm{ijkl}}=$ dependent variable, $\mu=$ overall mean, $\mathrm{S}_{\mathrm{i}}$ $=$ effect of square $\mathrm{i}, \mathrm{P}_{\mathrm{j}}=$ effect of period $\mathrm{j}, \mathrm{C}(\mathrm{S})_{\mathrm{ki}}=$ effect of cow $\mathrm{k}$ (within square i), $\mathrm{T}_{1}=$ effect of treatment l, $\mathrm{ST}_{\mathrm{il}}=$ interaction between square $\mathrm{i}$ and treatment $\mathrm{l}$, and $\mathrm{e}_{\mathrm{ijk} \mathrm{l}}=$ residual error. The following model was used for ruminal variables, for which repeated measurements over time were used ( $\mathrm{pH}$, ammonia, total free $\mathrm{AA}$, and individual and total VFA): 
Table 3. Effect of different protein supplements on DMI, milk production, and composition in lactating dairy cows ${ }^{1}$

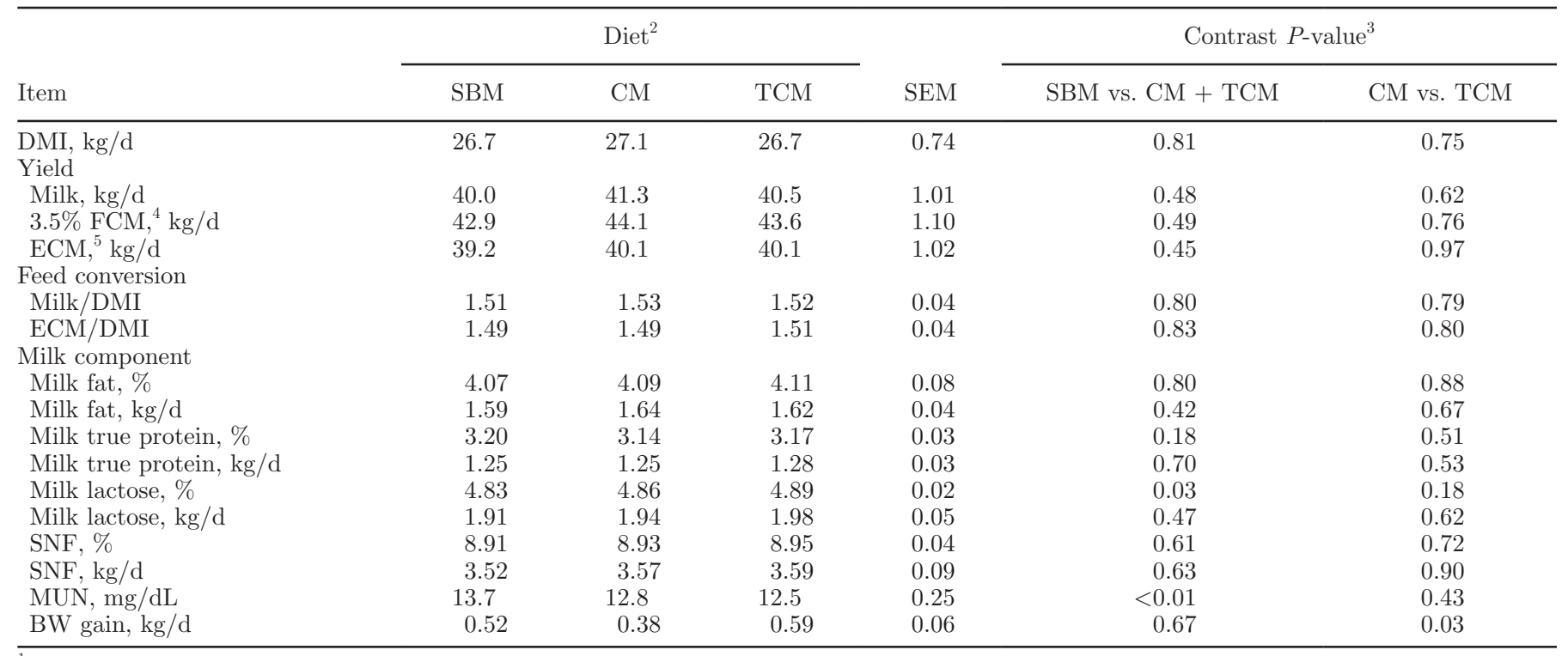

${ }^{1}$ Data from 45 lactating cows.

${ }^{2} \mathrm{SBM}=$ dietary treatment with solvent soybean meal as protein supplement; $\mathrm{CM}=$ dietary treatment with canola meal as protein supplement; $\mathrm{TCM}=$ dietary treatment with treated canola meal as protein supplement.

${ }^{3}$ Orthogonal contrasts for the effects of different protein supplements: SBM versus CM + TCM and CM versus TCM.

${ }^{4} \mathrm{FCM}=0.4318 \times$ milk yield $+16.23 \times$ fat yield (Sklan et al., 1992).

${ }^{5} \mathrm{ECM}=$ milk yield, $\mathrm{kg} / \mathrm{d} \times[(0.0929 \times \%$ fat $)+(0.0563 \times \%$ true protein $)+(0.0395 \times \%$ lactose $)] / 0.749$ (Krause and Combs, 2003$)$.

$$
\begin{aligned}
\mathrm{Y}_{\mathrm{ijklm}}=\mu & +\mathrm{S}_{\mathrm{i}}+\mathrm{P}_{\mathrm{j}}+\mathrm{C}(\mathrm{S})_{\mathrm{ki}}+\mathrm{T}_{1}+\mathrm{ST}_{\mathrm{il}} \\
& +\mathrm{Z}_{\mathrm{m}}+\mathrm{ZT}_{\mathrm{ml}}+\mathrm{e}_{\mathrm{ijklm},}
\end{aligned}
$$

where $\mathrm{Y}_{\mathrm{ijk} k \mathrm{~m}}=$ dependent variable, $\mu=$ overall mean, $\mathrm{S}_{\mathrm{i}}$ $=$ effect of square $\mathrm{i}, \mathrm{P}_{\mathrm{j}}=$ effect of period $\mathrm{j}, \mathrm{C}(\mathrm{S})_{\mathrm{ki}}=$ effect of cow k (within square i), $\mathrm{T}_{1}=$ effect of treatment $1, \mathrm{ST}_{\mathrm{il}}=$ interaction between square $\mathrm{i}$ and treatment $\mathrm{l}$, $\mathrm{Z}_{\mathrm{m}}=$ effect of time $\mathrm{m}, \mathrm{ZT}_{\mathrm{ml}}=$ interaction between time $\mathrm{m}$ and treatment $\mathrm{l}$, and $\mathrm{e}_{\mathrm{ijk} \mathrm{k}}=$ residual error. All terms were considered fixed except $\mathrm{C}(\mathrm{S})_{\mathrm{ki}}$ and $\mathrm{e}_{\mathrm{ijklm}}$, which were considered random. The covariance structure autoregressive was selected based on best-fit Akaike information criterion. Degrees of freedom were calculated using the Kenward-Roger option. Orthogonal contrasts were used to compare the effects of different protein supplements: SBM versus $\mathrm{CM}+\mathrm{TCM}$ and $\mathrm{CM}$ versus TCM. Statistical differences were declared at $P \leq 0.05$, and trends were declared at $0.05<P \leq 0.10$.

\section{RESULTS AND DISCUSSION}

\section{Experiment 1}

Diet did not statistically affect $(P>0.05)$ DMI and feed efficiency (Table 3). In a meta-analysis, Martineau et al. (2013) observed a positive response of $0.24 \mathrm{~kg} / \mathrm{d}$ in DMI for a CM diet compared with different protein supplements. In the present study we observed simi- lar numerical results; despite no statistical difference in DMI, inclusion of both $\mathrm{CM}$ at $11 \%$ in the TMR numerically increased DMI by $0.2 \mathrm{~kg} / \mathrm{d}$ compared with inclusion of SBM. Similar to our results, Shingfield et al. (2003) did not find differences in DMI between heattreated rapeseed meal expeller and SBM for dairy cows fed grass silage-based diets.

A diet effect was not observed $(P>0.05)$ on yield of milk, 3.5\% FCM, and ECM (Table 3). Despite no statistically significant effects of diet, yield of milk, $3.5 \% \mathrm{FCM}$, and ECM increased on average 0.9, 1.0, and $0.9 \mathrm{~kg} / \mathrm{d}$, respectively, for cows fed both CM compared with SBM. Two meta-analyses evaluating the effects of diets with CM versus SBM or other protein supplements reported an increase of milk yield for CM diets (Huhtanen et al., 2011; Martineau et al., 2013). Furthermore, Broderick et al. (2015) found an increase in milk yield $(0.9 \mathrm{~kg} / \mathrm{d})$ and ECM $(0.4 \mathrm{~kg} / \mathrm{d})$ when replacing SBM with CM. Given that we observed similar or greater numerical differences for the same variables compared with the literature, it is likely that our study lacked the statistical power needed to detect a significant difference in milk yield.

In the present study, cows fed the CM diet had an average numerical increase of $0.8 \mathrm{~kg}$ of milk/d when compared with cows fed the TCM diet. Extrusion plus molasses was used to treat CM, and, based on our results of RUP flow at the omasal canal, the TCM diet 
Table 4. Effect of different protein supplements on nitrogen excretion and apparent digestibility in lactating dairy cows ${ }^{1}$

\begin{tabular}{|c|c|c|c|c|c|c|}
\hline \multirow[b]{2}{*}{ Item } & \multicolumn{3}{|c|}{$\operatorname{Diet}^{2}$} & \multirow[b]{2}{*}{ SEM } & \multicolumn{2}{|c|}{ Contrast $P$-value ${ }^{3}$} \\
\hline & SBM & $\mathrm{CM}$ & TCM & & SBM vs. CM + TCM & CM vs. TCM \\
\hline Milk protein $\mathrm{N}, \%$ of $\mathrm{N}$ intake & 30.7 & 29.2 & 30.1 & 0.87 & 0.32 & 0.48 \\
\hline \multicolumn{7}{|l|}{ Urinary excretion } \\
\hline Urine volume,${ }^{4} \mathrm{~L} / \mathrm{d}$ & 28.4 & 30.2 & 28.8 & 1.44 & 0.54 & 0.50 \\
\hline Urea $N, g / d$ & 157 & 152 & 147 & 5.0 & 0.22 & 0.44 \\
\hline Urea $\mathrm{N}, \%$ of total urinary $\mathrm{N}$ & 72.2 & 69.2 & 68.4 & 0.90 & $<0.01$ & 0.52 \\
\hline Allantoin, mmol/d & 495 & 499 & 526 & 17.2 & 0.41 & 0.28 \\
\hline Uric acid, $\mathrm{mmol} / \mathrm{d}$ & 63.6 & 57.4 & 59.0 & 3.46 & 0.22 & 0.75 \\
\hline Purine derivatives, ${ }^{5} \mathrm{mmol} / \mathrm{d}$ & 558 & 556 & 585 & 19.7 & 0.62 & 0.31 \\
\hline Microbial N flow, ${ }^{6} \mathrm{~g} / \mathrm{d}$ & 376 & 382 & 388 & 14.5 & 0.62 & 0.78 \\
\hline \multicolumn{7}{|l|}{ Fecal N excretion } \\
\hline $\mathrm{CP}$ & 64.7 & 68.9 & 67.3 & 0.68 & $<0.01$ & 0.09 \\
\hline $\mathrm{NDF}$ & 45.1 & 49.1 & 47.1 & 0.80 & $<0.01$ & 0.08 \\
\hline
\end{tabular}

${ }^{1}$ Data from 45 lactating cows.

${ }^{2} \mathrm{SBM}=$ dietary treatment with solvent soybean meal as protein supplement; $\mathrm{CM}=$ dietary treatment with canola meal as protein supplement; $\mathrm{TCM}=$ dietary treatment with treated canola meal as protein supplement.

${ }^{3}$ Orthogonal contrasts for the effects of different protein supplements: SBM vs. CM + TCM and CM vs. TCM.

${ }^{4}$ Estimated from creatinine concentration in spot urine samples assuming an excretion of $29 \mathrm{mg}$ of creatinine/kg of BW (Valadares et al., 1999).

${ }^{5}$ Allantoin plus uric acid.

${ }^{6}$ Estimated from urinary excretion of purine derivatives according to Valadares et al. (1999).

was not effective in increasing RUP flow compared with the CM diet. It is well known that extrusion may be an effective method to increase the RUP content of protein supplements (Solanas et al., 2005). However, in some cases it may not increase RUP, or it may decrease AA availability due to overheating (Deacon et al., 1988; Mustafa et al., 2003). We speculate that the extrusion process was not effective in increasing the RUP content of $\mathrm{CM}$ due to the reduction of true proteinsoluble fraction in $\mathrm{CM}$ during the heating process. As shown in previous studies, the soluble protein fraction of CM may escape ruminal degradation, thus contributing to the RUP fraction of CM (Hedqvist and Udén, 2006; Bach et al., 2008). Furthermore, Ahvenjärvi et al. (1999) found a decrease in intake and omasal flow of true protein-soluble fraction and no difference in omasal flows of neutral detergent-soluble protein and neutral detergent-insoluble protein fractions for cows fed a diet with heat-moisture rapeseed cake compared with rapeseed meal. Therefore, the extrusion process of CM may decrease the soluble content of CM that would escape ruminal degradation and, thus, RUP flow. This may explain why the extrusion process in the present study did not increase the RUP content of the TCM diet. In addition, it is likely that in the present study the extrusion process decreased apparent total-tract digestibility of nutrients (DM, OM, CP, and NDF) because there was a tendency $(P=0.10)$ for total-tract digestibility of those nutrients to be lower for the TCM diet compared with the CM diets (Table 4). Furthermore, according to Newkirk et al. (2003), processing at elevated temperatures may decrease the AA bioavailability, which may explain the numerical differences in milk yield between CM diets.

Diet did not affect $(P>0.05)$ milk fat, milk true protein, and SNF yields and concentrations (Table 3 ). However, both $\mathrm{CM}$ diets increased $(P=0.03)$ milk lactose concentration. Despite this increase in lactose concentration, the magnitude of this difference does not seem to be biologically relevant.

Both CM diets decreased $(P<0.01)$ MUN by $8 \%$ compared with the SBM diet (Table 3), potentially indicating an improvement in $\mathrm{N}$ utilization for the $\mathrm{CM}$ diets. The reduction in MUN in cows fed the CM diets may be related to the increased concentration of plasma branched-chain AA (BCAA). Appuhamy et al. (2011) reported that infusion of $60 \mathrm{~g} / \mathrm{d}$ of $\mathrm{BCAA}$ did not increase milk protein efficiency but decreased MUN. Therefore, they speculated that infusion of BCAA may promote the synthesis of other body tissue proteins rather than an increase in AA catabolism. In addition, Martineau et al. (2014) reported a reduction in MUN 
and an increase in plasma concentration of BCAA for cows fed CM compared with other protein supplements. Shingfield et al. (2003) also found a reduction in BUN and an increase in plasma His, EAA, and BCAA concentrations in cows fed either heat-treated rapeseed expeller or SBM diets. Moreover, both CM diets decreased $(P<0.01)$ urinary urea $\mathrm{N}$ (\% of total urinary $\mathrm{N} ; 68.8$ vs. $72.2 \%$ for $\mathrm{CM}$ diets and SBM, respectively) and fecal N (\% of total $\mathrm{N}$ intake; 29.7 vs. $31.6 \%$ for CM diets and SBM, respectively; Table 4). In agreement with our results, Broderick et al. (2015) observed a significant decrease in MUN and excretion of urinary urea $\mathrm{N}$ for cows fed CM compared with SBM. The reduction in urinary urea $\mathrm{N}$ may indicate a potential to reduce the environmental impact of cows fed CM compared with SBM.

Diet did not affect $(P>0.05)$ urinary volume or urinary excretion of allantoin, uric acid, total PD, and estimated microbial $\mathrm{N}$ flow (Table 4). The across-diets average values observed in the present study were 29.1 $\mathrm{L} / \mathrm{d}$ for urine volume and 507, 60 , and $566 \mathrm{mmol} / \mathrm{d}$ for allantoin, uric acid, and total PD excretion, respectively. Our data are within the range of values observed in previous studies for those variables (Reynal et al., 2005; Colmenero and Broderick, 2006). The dietary average of microbial $\mathrm{N}$ flow estimated using PD as a microbial marker in the present study was $382 \mathrm{~g} / \mathrm{d}$, which was overestimated by $21 \%$ compared with microbial NAN flow (g/d) measured using ${ }^{15} \mathrm{~N}$ as a microbial marker. Our results are in agreement with previous results reported in the literature, where Reynal et al. (2005) found $22 \%$ overestimation and Faciola and Broderick (2014) found $28 \%$ overestimation of microbial N flow when comparing these microbial markers. Despite these differences, Reynal et al. (2005) reported that using PD in spot urine samples as a microbial marker was as effective as using ${ }^{15} \mathrm{~N}$ for detecting treatment differences in microbial $\mathrm{N}$ flow, which agrees with the results of the present study, where no dietary effects of microbial $\mathrm{N}$ flow were observed using either marker $\left(\mathrm{PD}\right.$ or $\left.{ }^{15} \mathrm{~N}\right)$.

Diets affected $(P<0.01)$ apparent total-tract digestibility of DM, OM, CP, and NDF (Table 4). Mean apparent total-tract digestibility for the CM diets was 1.9, $1.7,3.4$, and $3.0 \%$ units greater than that for the SBM diet for DM, OM, CP, and NDF, respectively. The increase in DM and OM digestibility may be explained by the greater digestibility of $\mathrm{CP}$ and $\mathrm{NDF}$, which are substantial components of OM. In agreement with our results, Brito and Broderick (2007) found an increase in NDF digestibility for cows fed CM compared with SBM. The increase in CP digestibility is in line with our omasal data, where we observed a tendency $(P<$ $0.10)$ to increase the amount of $\mathrm{N}$ truly digested in the rumen and RDP supply at the omasal canal for both CM diets compared with SBM.

\section{Experiment 2}

Experiment 2 aimed to evaluate omasal nutrient flow and the ruminal fermentation pattern of the same dietary treatments used in experiment 1 (SBM, CM, and TCM). Diets did not affect $(P>0.05)$ DMI, nutrient flow at the omasal canal, or ruminal digestibility of OM, NDF, and ADF (Table 5). In agreement with our results, Paula et al. (2017) did not observe differences in ruminal digestibility of $\mathrm{OM}, \mathrm{NDF}$, and $\mathrm{ADF}$ between diets containing CM with different RUP content and between CM diets versus the SBM diet in an in vitro study. Brito et al. (2007) found similar values for OM truly digested in the rumen (OMTDR) for diets containing SBM ( $65.5 \%$ of OM intake) or CM ( $63.3 \%$ of OM intake). Furthermore, Chibisa et al. (2012) found $62.7 \%$ for OMTDR for a diet with inclusion of $8 \%$ of CM. In the present study, overall OMTDR was $90 \%$ for OM total-tract digestibility, $63.4 \%$ for ruminal digestibility (Table 5), and $70.3 \%$ for total-tract digestibility (Table 4). Therefore, our data are in line with the expected values for ruminal and total-tract $\mathrm{OM}$ digestibility.

The average across diets for ruminal NDF digestibility in the present study was $31.4 \%$. Ruminal NDF digestibility was $67 \%$ of total-tract NDF digestibility. Ruminal NDF digestibility values observed in our study were lower than the values reported in another study in which TCM was used as a protein supplement for dairy cows (Krizsan et al., 2017). However, they were similar to values observed in high-producing cows using omasal sampling. Faciola and Broderick (2014) found that ruminal NDF digestibility was $63 \%$ of total-tract NDF digestibility. Factors that may explain these differences include DMI, rate of passage, and milk yield.

Diet did not affect $(P>0.05)$ estimated nonmicrobial NAN (NMNAN) flow, total microbial NAN flow, and efficiency of microbial protein synthesis. However, an increase was observed $(P=0.04)$ in dietary $\mathrm{N}$ intake and RDP supply $(P=0.01)$, and a tendency $(P=0.10)$ for an increase was observed in $\mathrm{N}$ truly digested in the rumen when both $\mathrm{CM}$ diets were fed compared with the SBM diet (Table 6). Cows fed CM had a numerically greater DMI (0.9 kg) compared with cows fed SBM, which explained the greater $\mathrm{N}$ intake for cows fed CM. Consequently, more $\mathrm{N}$ was available to the rumen microorganisms to degrade, which may explain the increase of $\mathrm{N}$ truly digested in the rumen and the greater RDP supply for both CM diets. Studies comparing ruminal $\mathrm{CP}$ degradability of $\mathrm{CM}$ with other protein supplements have reported inconsistent results. 
Table 5. Effect of different protein supplements on intake; flow at the omasal canal; and ruminal digestibility of DM, OM, NDF, and ADF in lactating dairy cows ${ }^{1}$

\begin{tabular}{|c|c|c|c|c|c|c|}
\hline \multirow[b]{2}{*}{ Item } & \multicolumn{3}{|c|}{ Diet $^{2}$} & \multirow[b]{2}{*}{ SEM } & \multicolumn{2}{|c|}{ Contrast $P$-value ${ }^{3}$} \\
\hline & SBM & $\mathrm{CM}$ & TCM & & $\mathrm{SBM}$ vs. $\mathrm{CM}+\mathrm{TCM}$ & CM vs. TCM \\
\hline Intake, $\mathrm{kg} / \mathrm{d}$ & 25.4 & 26.0 & 26.7 & 1.62 & 0.28 & 0.48 \\
\hline Flow at the omasal canal, $\mathrm{kg} / \mathrm{d}$ & 18.9 & 19.3 & 19.8 & 1.33 & 0.34 & 0.52 \\
\hline Apparently digested in the rumen, $\mathrm{kg} / \mathrm{d}$ & 6.42 & 6.70 & 6.90 & 0.53 & 0.34 & 0.69 \\
\hline$\%$ of DMI & 25.3 & 25.9 & 25.8 & 1.62 & 0.59 & 0.94 \\
\hline Flow at the omasal canal, $\mathrm{kg} / \mathrm{d}$ & 14.2 & 14.4 & 15.3 & 0.91 & 0.25 & 0.23 \\
\hline Apparently digested in the rumen, $\mathrm{kg} / \mathrm{d}$ & 9.48 & 9.62 & 9.28 & 0.89 & 0.92 & 0.72 \\
\hline$\%$ of OM intake & 39.8 & 40.1 & 37.4 & 2.24 & 0.66 & 0.37 \\
\hline Truly digested in the rumen, $\mathrm{kg} / \mathrm{d}$ & 15.1 & 15.5 & 15.1 & 1.12 & 0.81 & 0.72 \\
\hline$\%$ of OM intake & 64.3 & 64.4 & 61.6 & 1.82 & 0.46 & 0.22 \\
\hline \multicolumn{7}{|l|}{$\mathrm{NDF}$} \\
\hline Intake, $\mathrm{kg} / \mathrm{d}$ & 7.63 & 7.71 & 8.30 & 0.54 & 0.33 & 0.76 \\
\hline Flow at the omasal canal, $\mathrm{kg} / \mathrm{d}$ & 3.36 & 3.12 & 3.63 & 0.32 & 0.96 & 0.25 \\
\hline Apparently digested in the rumen, $\mathrm{kg} / \mathrm{d}$ & 1.70 & 1.82 & 1.83 & 0.43 & 0.75 & 0.98 \\
\hline$\%$ of ADF intake & 34.0 & 36.5 & 32.7 & 5.94 & 0.62 & 0.91 \\
\hline
\end{tabular}

${ }^{1}$ Data from 6 ruminally cannulated cows.

${ }^{2} \mathrm{SBM}=$ dietary treatment with solvent soybean meal as protein supplement; $\mathrm{CM}=$ dietary treatment with canola meal as protein supplement; $\mathrm{TCM}=$ dietary treatment with treated canola meal as protein supplement.

${ }^{3}$ Orthogonal contrasts for the effects of different protein supplements: SBM vs. CM + TCM and CM vs. TCM.

Paz et al. (2014) found greater ruminal CP degradability for CM compared with SBM (75.5 vs. $68.8 \%$ of CP, respectively), whereas Maxin et al. (2013b) observed lower ruminal CP degradability for CM compared with SBM (47.5 vs. $58.5 \%$ of CP, respectively). Both studies estimated ruminal CP degradability of these protein supplements as a sole ingredient using in situ methodology. Previous studies comparing the effect of $\mathrm{CM}$ and SBM in the total diet (Rinne et al., 2015; Paula et al., 2017) did not observe differences in ruminal N metabolism. The inconsistency between the present study and these previous studies may be attributable to a DMI effect because in both studies the DMI was not different.

We hypothesized that treating CM by extrusion would improve the flow of RUP at the omasal canal compared with regular CM. However, our results did not support this hypothesis; treating CM by extrusion did not affect the RUP flow for TCM compared with CM. Therefore, our results indicate that the extrusion process applied to CM was not effective in enhancing RUP flow. As mentioned earlier, to our knowledge there are no data in the literature reporting RUP flow when TCM was fed as the main protein supplement for lactating dairy cows fed corn- or alfalfa silage-based diets. Ahvenjärvi et al. (1999) did not observe differences between effects of rapeseed meal and heat-moisture-treated rapeseed cake on dietary NAN and microbial NAN flow at the omasal canal for cows fed a grass silage- and barleybased diet. Recently, Krizsan et al. (2017) observed a linear increase in NMNAN and a tendency to decrease bacterial NAN flow and bacterial efficiency when incremental amounts of TCM were added to grass silagebased diets. As reported in previous studies, increased flow of NMNAN to the small intestine is often related to a decrease in microbial NAN flow (Santos et al., 1998; Ipharraguerre and Clark, 2005). In the present study we did not observe differences in microbial NAN and NMNAN flows at the omasal canal, possibly due to the ineffectiveness of the extrusion process in increasing the RUP content in CM as earlier discussed.

However, some studies compared effects of regular $\mathrm{CM}$ with heat-treated $\mathrm{CM}$ or $\mathrm{CM}$ treated with heat and lignosulfonate on the performance of lactating dairy cows (Rinne et al., 1999; Wright et al., 2005; Mutsvangwa et al., 2016). In these studies, the authors did not find greater animal performance when only heat treatment was applied to the CM compared with regular CM. However, Wright et al. (2005) observed an increase in the performance of cows when both heat and lignosulfonate were applied to regular CM. In addition, von Keyserlingk et al. (2000) using in situ methodology reported a decrease in ruminal digestibility and an increase in intestinal digestibility for the canola treated with heat plus lignosulfonate compared with untreated 
Table 6. Effect of different protein supplements on intake and flow of $\mathrm{N}$ fractions at the omasal canal in lactating dairy cows ${ }^{1}$

\begin{tabular}{|c|c|c|c|c|c|c|}
\hline Item $^{2}$ & \multicolumn{3}{|c|}{ Diet $^{3}$} & SEM & \multicolumn{2}{|c|}{ Contrast $P$-value ${ }^{4}$} \\
\hline Dietary $\mathrm{N}$ intake, $\mathrm{g} / \mathrm{d}$ & 625 & 668 & 679 & 39 & 0.04 & 0.64 \\
\hline \multicolumn{7}{|l|}{ Omasal flows } \\
\hline Total NAN, g/d & 669 & 688 & 671 & 50 & 0.82 & 0.76 \\
\hline NAN, $\%$ of $\mathrm{N}$ intake & 107 & 101 & 99 & 4.3 & 0.16 & 0.76 \\
\hline $\mathrm{N}$ truly digested in the rumen, $\mathrm{g} / \mathrm{d}$ & 413 & 472 & 471 & 29 & 0.10 & 0.97 \\
\hline$\%$ of diet $\mathrm{CP}$ & 66.1 & 69.0 & 69.9 & 3.5 & 0.40 & 0.85 \\
\hline$\%$ of DMI & 10.2 & 11.1 & 11.1 & 0.57 & 0.16 & 0.95 \\
\hline \multicolumn{7}{|l|}{ RUP flow } \\
\hline $\mathrm{kg} / \mathrm{d}$ & 1.33 & 1.28 & 1.30 & 0.18 & 0.78 & 0.92 \\
\hline$\%$ of $\operatorname{diet} \mathrm{CP}$ & 33.9 & 31.0 & 30.1 & 3.5 & 0.41 & 0.85 \\
\hline$\%$ of DMI & 5.2 & 5.0 & 4.8 & 0.52 & 0.56 & 0.81 \\
\hline \multicolumn{7}{|l|}{ NMNAN flow } \\
\hline $\mathrm{g} / \mathrm{d}$ & 185 & 176 & 190 & 7.89 & 0.82 & 0.20 \\
\hline$\%$ of microbial NAN & 38.7 & 37.2 & 38.9 & 2.36 & 0.78 & 0.56 \\
\hline \multicolumn{7}{|l|}{ PAB-NAN } \\
\hline $\mathrm{g} / \mathrm{d}$ & 298 & 306 & 298 & 35.1 & 0.89 & 0.84 \\
\hline$\%$ of microbial NAN & 61.3 & 62.8 & 61.1 & 2.36 & 0.78 & 0.56 \\
\hline \multicolumn{7}{|l|}{ Total microbial NAN } \\
\hline $\mathrm{g} / \mathrm{d}$ & 482 & 482 & 488 & 40.7 & 0.94 & 0.90 \\
\hline$\%$ of total NAN & 72.1 & 70.3 & 72.7 & 2.49 & 0.79 & 0.37 \\
\hline Microbial efficiency, $\mathrm{g}$ of NAN $/ \mathrm{kg}$ of OMTDR & 32.2 & 30.5 & 32.8 & 1.95 & 0.81 & 0.38 \\
\hline
\end{tabular}

${ }^{1}$ Data from 6 ruminally cannulated cows.

${ }^{2}$ NMNAN = nonmicrobial NAN; FAB-NAN = fluid-associated bacterial NAN; PAB-NAN = particle-associated bacterial NAN; OMTDR = OM truly digested in the rumen.

${ }^{3} \mathrm{SBM}=$ dietary treatment with solvent soybean meal as protein supplement; $\mathrm{CM}=$ dietary treatment with canola meal as protein supplement; $\mathrm{TCM}=$ dietary treatment with treated canola meal as protein supplement.

${ }^{4}$ Orthogonal contrasts for the effects of different protein supplements: SBM vs. CM + TCM and CM vs. TCM.

and heat-treated canola. It is likely that the process used to treat $\mathrm{CM}$ in the present study was not effective to enhance the RUP flow to the small intestine, which may explain the lack of response to TCM.

The averages across diets in the present study for NMNAN and total microbial NAN flow were 190 and $484 \mathrm{~g} / \mathrm{d}$, respectively. When expressed as a proportion of NAN intake, the dietary average values were 28 and $72 \%$ for NMNAN and total microbial NAN, respectively. These values are within the range of values observed in previous studies with lactating cows, which ranged from 28 to $33 \%$ for NMNAN (\% of NAN intake) and 67 to $72 \%$ for total microbial NAN (\% of NAN intake; Brito et al., 2007; Chibisa et al., 2012; Faciola and Broderick, 2014).

Diets did affect $(P=0.02)$ ruminal ammonia $\mathrm{N}$ (Table 7). Both $\mathrm{CM}$ diets had greater ruminal $\mathrm{NH}_{3} \mathrm{~N}$ concentration compared with SBM $(6.68 \mathrm{mg} / \mathrm{dL}$ for the mean of both CM diets vs. $5.91 \mathrm{mg} / \mathrm{dL}$ for $\mathrm{SBM})$. No differences $(P=0.69)$ were observed between the $2 \mathrm{CM}$ diets. According to Reynolds and Kristensen (2008), ruminal $\mathrm{NH}_{3}-\mathrm{N}$ is positively correlated with $\mathrm{N}$ intake and, as previously discussed, cows fed both CM diets had a greater $\mathrm{N}$ intake, which may explain the greater ruminal $\mathrm{NH}_{3}-\mathrm{N}$ concentration for the $\mathrm{CM}$ diets. Diet did not affect $(P>0.05)$ ruminal concentration of free AA; total VFA; total branched-chain VFA $(\mathrm{m} M)$; molar proportions of acetate, propionate, butyrate, valerate, and isobutyrate; and $\mathrm{pH}$ (Table 7). In agrement with our results, Brito and Broderick (2007) comparing diets with SBM or CM for lactating dairy cows did not find differences in total VFA, acetate, butyrate, isobutyrate, and valerate. However, we observed an increase $(P=$ 0.03) in the molar proportion of isovalerate when TCM was fed compared with CM. Conversely, Ahvenjärvi et al. (1999) reported lower molar proportion of isovalerate for heat-moisture-treated rapeseed cake diet compared with rapeseed meal. The inconsistency between these studies may be attributable to the type of canola used (heat-treated rapeseed cake vs. heat-treated CM) or to the different heating processes used to treat the protein supplements. 
Table 7. Effect of different protein supplements on ruminal $\mathrm{pH}$ and metabolite concentrations ${ }^{1}$

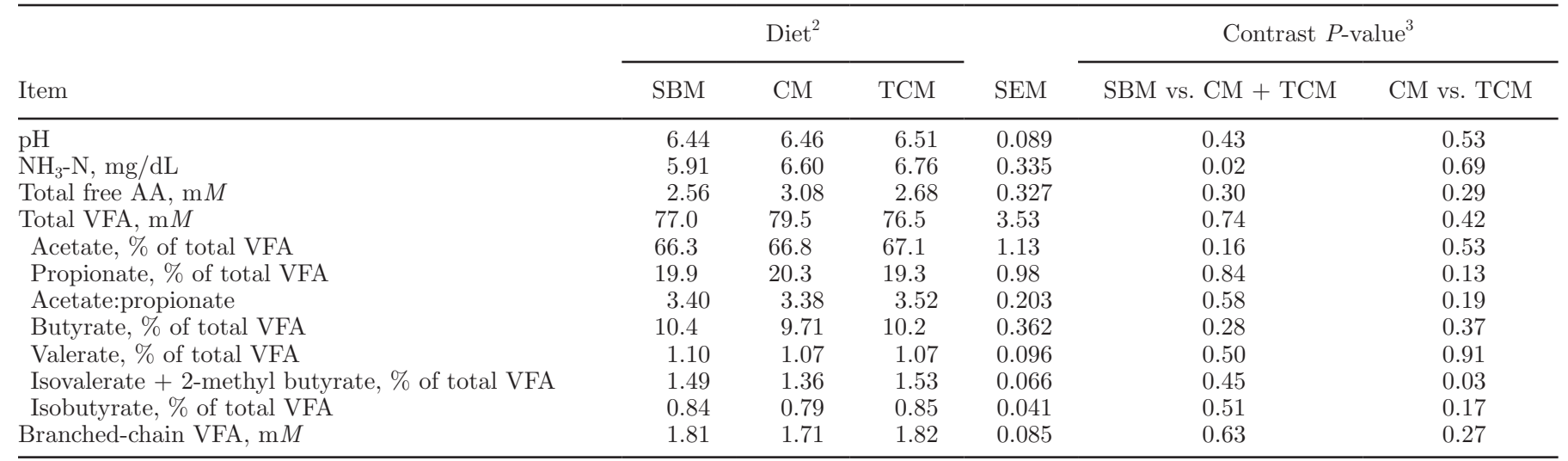

${ }^{1}$ Data from 6 ruminally cannulated cows.

${ }^{2} \mathrm{SBM}=$ dietary treatment with solvent soybean meal as protein supplement; $\mathrm{CM}=$ dietary treatment with canola meal as protein supplement; $\mathrm{TCM}=$ dietary treatment with treated canola meal as protein supplement.

${ }^{3}$ Orthogonal contrasts for the effects of different protein supplements: SBM vs. CM + TCM and CM vs. TCM.

\section{CONCLUSIONS}

Our results indicate that under the conditions of the present study, treating CM by extrusion was not effective in improving CM utilization by lactating dairy cows. Diets did not affect performance of dairy cows. However, compared with the SBM diet, both CM diets increased digestibility and $\mathrm{N}$ intake, tended to increase $\mathrm{RDP}$ supply at the omasal canal and $\mathrm{N}$ truly digested in the rumen, and tended to decrease MUN and N excretion in feces and urine. Therefore, CM may have a reduced environmental impact compared with SBM due to lower urea $\mathrm{N}$ excretion as a proportion of total urinary $\mathrm{N}$.

\section{ACKNOWLEDGMENTS}

The authors thank the Canola Council of Canada (Winnipeg, MB, Canada) for partial funding support; the farm crew for harvesting and storing the feedstuffs used in this trial and Kurt Pickar for feeding and animal care at the U.S. Dairy Forage Research Center Farm (Prairie du Sac, WI); and W. Radloff and M. Becker (U.S. Dairy Forage Research Center), Tiago Barros (University of Wisconsin), Lorrayny Galoro da Silva, and Hugo Fernando Monteiro (University of Florida) for conducting laboratory analyses and for assisting with sample collection. We also thank Fernando Drago (State University of São Paulo, Pirassununga, Brazil) for his help with the omasal samples. Mention of any trademark or proprietary product in this paper does not constitute a guarantee or warranty of the product by the USDA or the Agricultural Research Service and does not imply its approval to the exclusion of other products that also may be suitable.

\section{REFERENCES}

Ahvenjärvi, S., A. Vanhatalo, P. Huhtanen, and T. Varvikko. 1999. Effects of supplementation of a grass silage and barley diet with urea, rapeseed meal and heat-moisture-treated rapeseed cake on omasal digesta flow and milk production in lactating dairy cows. Acta Agric. Scand. Anim. Sci. 49:179-189.

Ahvenjärvi, S., A. Vanhatalo, P. Huhtanen, and T. Varvikko. 2000. Determination of reticulo-rumen and whole-stomach digestion in lactating cows by omasal canal or duodenal sampling. Br. J. Nutr. 83:67-77.

AOAC (Association of Official Analytical Chemists). 1990. Official Methods of Analysis. 15th ed. AOAC, Arlington, VA.

AOAC International. 2005. Official Methods of Analysis. 18th ed. AOAC International, Arlington, VA.

Appuhamy, J. A. D. R. N., J. R. Knapp, O. Becvar, J. Escobar, and M. D. Hanigan. 2011. Effects of jugular-infused lysine, methionine, and branched-chain amino acids on milk protein synthesis in highproducing dairy cows. J. Dairy Sci. 94:1952-1960.

Bach, A., M. Ruiz Moreno, M. Thrune, and M. D. Stern. 2008. Evaluation of the fermentation dynamics of soluble crude protein from three protein sources in continuous culture fermenters. J. Anim. Sci. 86:1364-1371.

Brito, A. F., and G. A. Broderick. 2007. Effects of different protein supplements on milk production and nutrient utilization in lactating dairy cows. J. Dairy Sci. 90:1816-1827.

Brito, A. F., G. A. Broderick, and S. M. Reynal. 2007. Effects of different protein supplements on omasal nutrient flow and microbial protein synthesis in lactating dairy cows. J. Dairy Sci. 90:18281841.

Broderick, G. A., and M. K. Clayton. 1997. A statistical evaluation of animal and nutritional factors influencing concentrations of milk urea nitrogen. J. Dairy Sci. 80:2964-2971.

Broderick, G. A., A. P. Faciola, and L. E. Armentano. 2015. Replacing dietary soybean meal with canola meal improves production and efficiency of lactating dairy cows. J. Dairy Sci. 98:5672-5687.

Brotz, P. G., and D. M. Schaefer. 1987. Simultaneous determination of lactic acid and volatile fatty acids in microbial fermentation extracts by gas-liquid chromatography. J. Microbiol. Methods 6:139-144.

Chibisa, G. E., D. Christensen, and T. Mutsvangwa. 2012. Effects of replacing canola meal as the major protein source with wheat dried distillers grains with solubles on ruminal function, microbial protein synthesis, omasal flow, and milk production in cows. J. Dairy Sci. 95:824-841. 
Cochran, R., D. Adams, J. Wallace, and M. Galyean. 1986. Predicting digestibility of different diets with internal markers: Evaluation of four potential markers. J. Anim. Sci. 63:1476-1483.

Colmenero, J. J., and G. Broderick. 2006. Effect of amount and ruminal degradability of soybean meal protein on performance of lactating dairy cows. J. Dairy Sci. 89:1635-1643.

Deacon, M. A., G. De Boer, and J. J. Kennelly. 1988. Influence of JetSploding and extrusion on ruminal and intestinal disappearance of canola and soybeans. J. Dairy Sci. 71:745-753.

Faciola, A. P., and G. A. Broderick. 2014. Effects of feeding lauric acid or coconut oil on ruminal protozoa numbers, fermentation pattern, digestion, omasal nutrient flow, and milk production in dairy cows. J. Dairy Sci. 97:5088-5100.

France, J., and R. C. Siddons. 1986. Determination of digesta flow by continuous marker infusion. J. Theor. Biol. 121:105-119.

Hedqvist, H., and P. Udén. 2006. Measurement of soluble protein degradation in the rumen. Anim. Feed Sci. Technol. 126:1-21.

Huhtanen, P., P. G. Brotz, and L. D. Satter. 1997. Omasal sampling technique for assessing fermentative digestion in the forestomach of dairy cows. J. Anim. Sci. 75:1380-1392.

Huhtanen, P., M. Hetta, and C. Swensson. 2011. Evaluation of canola meal as a protein supplement for dairy cows: A review and a metaanalysis. Can. J. Anim. Sci. 91:529-543.

Huhtanen, P., K. Kaustell, and S. Jaakkola. 1994. The use of internal markers to predict total digestibility and duodenal flow of nutrients in cattle given six different diets. Anim. Feed Sci. Technol. 48:211-227.

Ipharraguerre, I. R., and J. H. Clark. 2005. Impacts of the source and amount of crude protein on the intestinal supply of nitrogen fractions and performance of dairy cows. J. Dairy Sci. 88:E22-E37.

Khorasani, G. R., P. H. Robinson, and J. J. Kennelly. 1993. Effects of canola meal treated with acetic acid on rumen degradation and intestinal digestibility in lactating dairy cows. J. Dairy Sci. $76: 1607-1616$.

Krause, K. M., and D. Combs. 2003. Effects of forage particle size, forage source, and grain fermentability on performance and ruminal pH in midlactation cows. J. Dairy Sci. 86:1382-1397.

Krizsan, S. J., H. Gidlund, F. Fatehi, and P. Huhtanen. 2017. Effect of dietary supplementation with heat-treated canola meal on ruminal nutrient metabolism in lactating dairy cows. J. Dairy Sci. 100:8004-8017.

Martineau, R., D. Ouellet, and H. Lapierre. 2014. The effect of feeding canola meal on concentrations of plasma amino acids. J. Dairy Sci. 97:1603-1610.

Martineau, R., D. R. Ouellet, and H. Lapierre. 2013. Feeding canola meal to dairy cows: A meta-analysis on lactational responses. J. Dairy Sci. 96:1701-1714.

Maxin, G., D. Ouellet, and H. Lapierre. 2013a. Effect of substitution of soybean meal by canola meal or distillers grains in dairy rations on amino acid and glucose availability. J. Dairy Sci. 96:7806-7817.

Maxin, G., D. Ouellet, and H. Lapierre. 2013b. Ruminal degradability of dry matter, crude protein, and amino acids in soybean meal, canola meal, corn, and wheat dried distillers grains. J. Dairy Sci. 96:5151-5160.

Mustafa, A. F., C. Gonthier, and D. R. Ouellet. 2003. Effects of extrusion of flaxseed on ruminal and postruminal nutrient digestibilities. Arch. Tierernahr 57:455-463.

Mutsvangwa, T., D. Kiran, and S. Abeysekara. 2016. Effects of feeding canola meal or wheat dried distillers grains with solubles as a major protein source in low- or high-crude protein diets on ruminal fermentation, omasal flow, and production in cows. J. Dairy Sci. 99:1216-1227.

Newkirk, R. W., H. L. Classen, T. A. Scott, and M. J. Edney. 2003. The digestibility and content of amino acids in toasted and nontoasted canola meals. Can. J. Anim. Sci. 83:131-139.

NRC. 2001. Nutrient Requirements of Dairy Cattle. 7th rev. ed. Natl. Acad. Sci., Washington, DC.

Oser, B. L. 1965. Hawk's Physiological Chemistry. 14th ed. McGrawHill, New York, NY.
Paula, E. M., H. F. Monteiro, L. G. Silva, P. D. B. Benedeti, J. L. P. Daniel, T. Shenkoru, G. A. Broderick, and A. P. Faciola. 2017. Effects of replacing soybean meal with canola meal differing in rumen-undegradable protein content on ruminal fermentation and gas production kinetics using 2 in vitro systems. J. Dairy Sci. 100:5281-5292.

Paz, H., T. Klopfenstein, D. Hostetler, S. C. Fernando, E. CastilloLopez, and P. Kononoff. 2014. Ruminal degradation and intestinal digestibility of protein and amino acids in high-protein feedstuffs commonly used in dairy diets. J. Dairy Sci. 97:6485-6498.

Reynal, S. M., G. Broderick, and C. Bearzi. 2005. Comparison of four markers for quantifying microbial protein flow from the rumen of lactating dairy cows. J. Dairy Sci. 88:4065-4082.

Reynal, S. M., and G. A. Broderick. 2005. Effect of dietary level of rumen-degraded protein on production and nitrogen metabolism in lactating dairy cows. J. Dairy Sci. 88:4045-4064.

Reynolds, C. K., and N. B. Kristensen. 2008. Nitrogen recycling through the gut and the nitrogen economy of ruminants: An asynchronous symbiosis. J. Anim. Sci. 86:E293-E305.

Rinne, M., S. Jaakkola, T. Varvikko, and P. Huhtanen. 1999. Effects of type and amount of rapeseed feed on milk production. Acta Agric. Scand. Anim. Sci. 49:137-148.

Rinne, M., K. Kuoppala, S. Ahvenjärvi, and A. Vanhatalo. 2015. Dairy cow responses to graded levels of rapeseed and soya bean expeller supplementation on a red clover/grass silage-based diet. Animal 9:1958-1969

Roth, M. 1971. Fluorescence reaction for amino acids. Anal. Chem. $43: 880-882$.

Santos, F., J. Santos, C. Theurer, and J. Huber. 1998. Effects of rumen-undegradable protein on dairy cow performance: A 12-year literature review. J. Dairy Sci. 81:3182-3213.

Shingfield, K. J., A. Vanhatalo, and P. Huhtanen. 2003. Comparison of heat-treated rapeseed expeller and solvent-extracted soya-bean meal as protein supplements for dairy cows given grass silagebased diets. Anim. Sci. 77:305-317.

Siddons, R. C., J. Paradine, D. Beever, and P. Cornell. 1985. Ytterbium acetate as a particulate-phase digesta-flow marker. Br. J. Nutr. 54:509-519.

Sklan, D., R. Ashkenazi, A. Braun, A. Devorin, and K. Tabori. 1992. Fatty acids, calcium soaps of fatty acids, and cottonseeds fed to high yielding cows. J. Dairy Sci. 75:2463-2472.

Solanas, E., C. Castrillo, J. Balcells, and J. A. Guada. 2005. In situ ruminal degradability and intestinal digestion of raw and extruded legume seeds and soya bean meal protein. J. Anim. Physiol. Anim. Nutr. (Berl.) 89:166-171.

Udén, P., P. E. Colucci, and P. J. Van Soest. 1980. Investigation of chromium, cerium and cobalt as markers in digesta. Rate of passage studies. J. Sci. Food Agric. 31:625-632.

Valadares, R. F., G. A. Broderick, S. C. Valadares Filho, and M. K. Clayton. 1999. Effect of replacing alfalfa silage with high moisture corn on ruminal protein synthesis estimated from excretion of total purine derivatives. J. Dairy Sci. 82:2686-2696.

Van Soest, P. J., J. B. Robertson, and B. A. Lewis. 1991. Methods for dietary fiber, neutral detergent fiber, and nonstarch polysaccharides in relation to animal nutrition. J. Dairy Sci. 74:3583-3597.

Vogels, G. D., and C. Van der Drift. 1970. Differential analyses of glyoxylate derivatives. Anal. Biochem. 33:143-157.

von Keyserlingk, M. A., E. Weurding, M. L. Swift, C. F. Wright, J. A. Shelford, and L. J. Fisher. 2000. Effect of adding lignosulfonate and heat to canola screenings on ruminal and intestinal disappearance of dry matter and crude protein. Can. J. Anim. Sci. $80: 215-219$.

Wright, C. F., M. A. von Keyserlingk, M. L. Swift, L. J. Fisher, J. A. Shelford, and N. E. Dinn. 2005. Heat-and lignosulfonate-treated canola meal as a source of ruminal undegradable protein for lactating dairy cows. J. Dairy Sci. 88:238-243. 